\title{
Intrahepatic Cholangiocarcinoma with Lymphoepithelioma-Like Component
}

\author{
Tse-Ching Chen, M.D., Kwai-Fong Ng, M.D., Tseng-tong Kuo, M.D., Ph.D. \\ Department of Pathology, Chang Gung Memorial Hospital, Chang Gung University School of Medicine, \\ Kwei San, Taiwan
}

We present two cases of intrahepatic cholangiocarcinoma with lymphoepithelioma-like component. The patients included one woman and one man, aged 67 and 41 years, respectively. They presented with right upper quadrant pain and epigastralgia. Histologically, both tumors showed two distinct histological patterns with dense lymphoplasma cell infiltration. The first pattern was a well to moderately differentiated adenocarcinoma; the second component showed a feature similar to lymphoepithelioma-like carcinoma. Granulomatous reaction was noted in one case. Immunohistochemical study revealed that both tumors were immunoreactive with AE1/AE3, cytokeratin 7, and cytokeratin 19 but negative for carcinoembryonic antigen and cytokeratin 20 . The stromal lymphocytes were composed of predominantly $\mathrm{CD3}(+) \mathrm{T}$ cells. In situ hybridization for Epstein-Barr virus (EBV)-encoded RNA (EBER) showed positive nuclear signal in tumor cells but not in inflammatory cells in one case. The presence or absence of EBV genome was confirmed by polymerase chain reaction of LMP-1 gene in both cases. The LMP-1 gene also had a 30-bp deletion in Exon 3 as compared with the products from B95-8 cells. We further sequenced the PCR product and confirmed a 30-bp deletion between Nucleotide (nt) 168,282 and nt 168,253 corresponding to the B95-8 sequence. The clinical significance of 30 -bp deletion in Exon 3 of the LMP-1 gene in lymphoepithelioma-like carcinoma of the liver warrants further investigation.

KEY WORDS: Epstein-Barr virus, Latent membrane protein-1 gene, Liver, Lymphoepithelioma-like carcinoma.

Mod Pathol 2001;14(5):527-532

Copyright () 2001 by The United States and Canadian Academy of Pathology, Inc.

VOL. 14, NO. 5, P. 527, 2001 Printed in the U.S.A

Date of acceptance: January 11, 2001.

This work was supported by grants from the National Science Council of the Republic of China (NSC89-2314-B-182-011) and the Chang Gung Medical Research Fund (NMRP509 and CMRP799).

Address reprint requests to: Tse-Ching Chen, M.D., Department of Pathology, Chang Gung Memorial Hospital, Kwei San, Tao Yuan 333, Taiwan; e-mail: ctc323@mail.cgu.edu.tw; fax: 886-3-3280147.
Intrahepatic cholangiocarcinoma is a malignant tumor arising from biliary epithelium. Histologically, it is characterized by sclerotic stroma with rare prominent lymphocytic infiltration. Recently, three cases of hepatic lymphoepithelioma-like carcinoma (LELC) were reported (1-3). Two of the reported cases have been shown to have Epstein-Barr virus (EBV) sequence $(1,2)$. In this report, we describe two additional cases of intrahepatic cholangiocarcinoma with lymphoepithelioma-like component with immunohistochemical and EBV study.

\section{MATERIALS AND METHODS}

Two cases of intrahepatic cholangiocarcinoma with lymphoepithelioma-like component were retrieved from the surgical pathology file of Chang Gung Memorial Hospital from 1999 to 2000. Formalin-fixed and paraffin-embedded tissues were used for histopathologic, immunohistochemical, and in situ hybridization studies. The immunohistochemical studies were performed by using avidin-biotin-peroxidase complex method. A panel of antibodies was used and listed in Table 1. EBVencoded RNA (EBER) in situ hybridization studies were performed with DAKO fluorescein-conjugated EBV (EBER) PNA probe (complementary to two nuclear EBER RNAs encoded by EBV, DAKO A/S, Glostrup, Denmark) on 5- $\mu \mathrm{m}$-thick deparaffinized and proteinase K-pretreated tissues for 1.5 hours at $55^{\circ} \mathrm{C}$. After washing, the reaction was detected by the Dako PNA ISH detection Kit (DAKO A/S).

\section{Latent Membrane Protein-1 Gene Study}

Fresh tumor tissue was frozen in $-80^{\circ} \mathrm{C}$ until they were used. High molecular DNA was purified by phenol/chloroform extraction and followed by ethanol precipitation. DNA pellets were resuspended in distilled water. To examine the 30 -bp deletion in Exon 3 of the latent membrane protein-1 (LMP-1) gene, a set of primers, 9/11 described by Knecht et al. (4), were used. The amplification reaction mixture contained $10 \mathrm{~mm}$ Tris HCL (pH 7.5), $50 \mathrm{~mm}$ 
TABLE 1. Antibodies Used in This Study

\begin{tabular}{lllc}
\hline Antibody & Source & Dilution & Pretreatment \\
\hline AE1/AE3 & BioGenex & $1: 202$ & TP \\
CEA & DAKO & $1: 50$ & TP \\
CK7 & BioGenex & $1: 50$ & PC \\
CK19 & BioGenex & $1: 200$ & PC \\
CK20 & BioGenex & $1: 50$ & PC \\
CD3 & DAKO & $1: 800$ & TP \\
CD20 & DAKO & $1: 1600$ & PC \\
CD21 & DAKO & $1: 50$ & TP
\end{tabular}

CEA, carcinoembryonic antigen; CK, cytokeratin; PC, pressure cooking in EDTA for 2 minutes or in citrate buffer for 3 minutes; TP, trypsinization for 20 minutes.

sodium chloride, $10 \mathrm{~mm}$ magnesium chloride, 1.5 mM dNTP, two primers ( $0.2 \mu \mathrm{M}$ each), and 2.5 units of Taq DNA polymerase. The amplification cycle included 1 minute of DNA denaturation at $95^{\circ} \mathrm{C}$ followed by 1 minute of annealing at $55^{\circ} \mathrm{C}$ and 1 minute of DNA extension at $72^{\circ} \mathrm{C}$. The amplification was repeated for 30 cycles. After the reaction, one tenth of the reaction mixture was fractioned electrophoretically in $6 \%$ polyacrylamide gel and visually inspected under ultraviolet light for the presence of DNA bands of appropriate size after ethidium-bromide staining. The PCR products were directly analyzed on the gel by size difference. DNA preparations from B95-8 and pT7 strains were used as controls.

DNA sequencing for the PCR products of the Exon 3 of LMP-1 gene was carried out using ABI PRISM dRhodamine terminator cycle sequencing ready reaction kit. Reaction products were analyzed on the ABI PRISM 377 DNA sequencer using the ABI PRISM sequencing software, Version 3.0.

\section{RESULTS}

\section{Clinical Histories}

\section{Case 1}

A 67-year-old female patient presented with right upper quadrant pain for several months. Imaging studies, including abdominal ultrasound and angiography, revealed a mixed echoic and hypervascular tumor in Segment 8. The liver tumor measured $5 \times 4.5 \mathrm{~cm}$. Serum anti-hepatitis virus C (HCV) antibody was positive, but hepatitis B surface antigen was negative. Serum tumor markers, including $\alpha$-fetoprotein and carcinoembryonic antigen, were within the normal range. A hepatectomy was performed. At operation, an enlarged lymph node was noted at the hepatoduodenal ligament. No tumor was detected in any other organs. The patient died of postoperative pancreatitis.

\section{Case 2}

A 41-year-old male patient, with a history of IgA nephropathy for 10 years, complained of epigastral- gia that he reported having had for 2 weeks. He was also a hepatitis B virus carrier. Abdominal ultrasound examination revealed a $3 \times 2-\mathrm{cm}$ hypoechoic tumor in segment 2. Angiographic study showed it to be a hypervascular tumor. Serum $\alpha$-fetoprotein was within the normal range. Serum anti-HCV antibody was negative. The liver nodule was resected. No evidence of recurrence or distant metastasis was found within an 8-month follow-up period.

\section{Pathologic Findings}

Both tumors were gray-white, rubbery, and nonencapsulated. Microscopically, both tumors shared similar histological features. They consisted of two distinct patterns and merged together. The first component consisted of irregular large and small glandular structures (Fig. 1A). The second pattern is composed of solid nests or irregular cords of large undifferentiated cells with vesicular nuclei, prominent nucleoli, and indistinct cell borders (Fig. 1B). This component was identical to LELC in morphology. Both components were associated with dense lymphoplasma cell infiltrations. Granulomatous reaction was also present with some multinucleated giant cells in Case 1 (Fig. 2). The group 12 lymph node taken from Case 1 was metastasized by both ordinary adenocarcinoma and lymphoepitheliomalike components. The background liver of Case 2 showed cirrhotic change without obvious activity.

The neoplastic cells from both ordinary adenocarcinoma and LELC component were strongly positive for AE1/A3. They were also immunoreactive with cytokeratin (CK) 7 and CK 19 (Fig. 3) but negative for carcinoembryonic antigen (CEA) and CK 20. The tumor cells were also not stained by CD21. The lymphoid stroma was composed of a mixture of $\mathrm{CD} 3(+)$ and $\mathrm{CD} 20(+)$ cells, with a predominance of CD3(+) T-cells.

\section{EBER In Situ Hybridization}

Case 1 showed positive nuclear EBER signals in neoplastic epithelial cells of both ordinary adenocarcinoma and LELC components (Fig. 4), whereas the inflammatory cells in the background were negative. In contrast, the neoplastic cells and the inflammatory cells in the background in Case 2 were all negative.

\section{LMP-1 Gene Study}

The presence or absence of EBV genome was confirmed by PCR of LMP-1 gene in both cases. In addition, the LMP-1 gene had a 30-bp deletion in Exon 3 as compared with the products from B95-8 cells (Fig. 5) in Case 1. We further sequenced the PCR product and confirmed a 30-bp deletion be- 


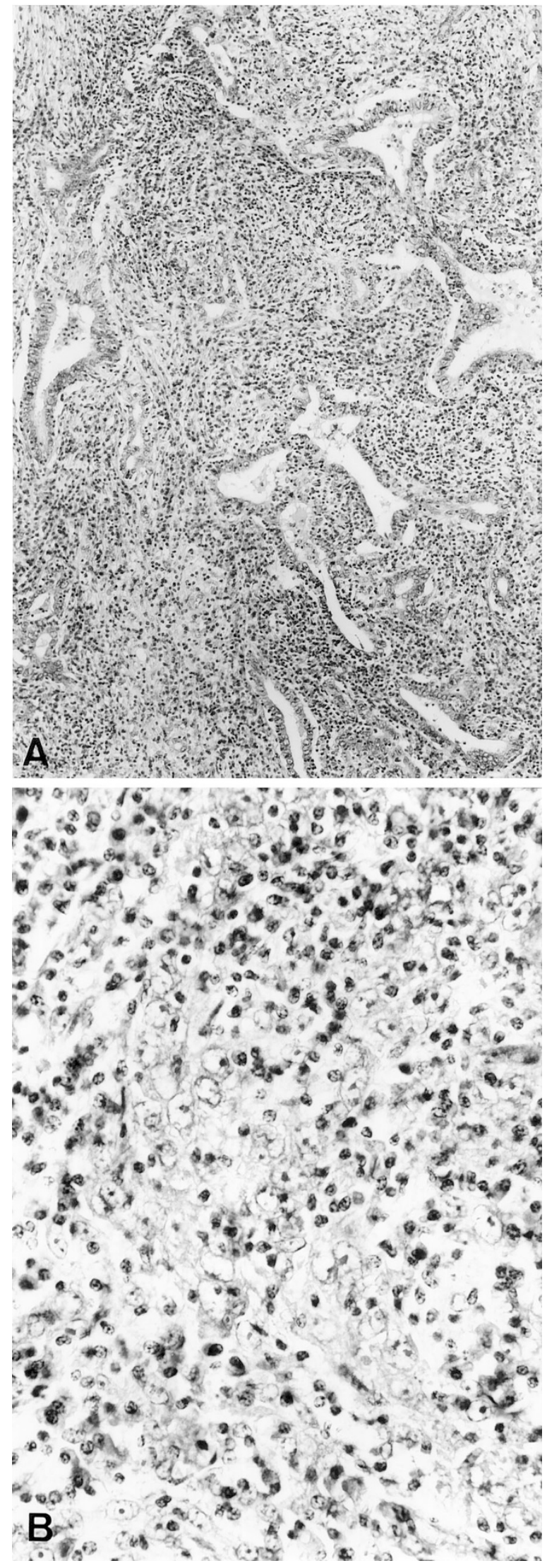

FIGURE 1. Both liver tumors showed large and small neoplastic glands (A) and lymphoepithelioma-like features (B) with dense infiltrates of plasma cells and lymphocytes.

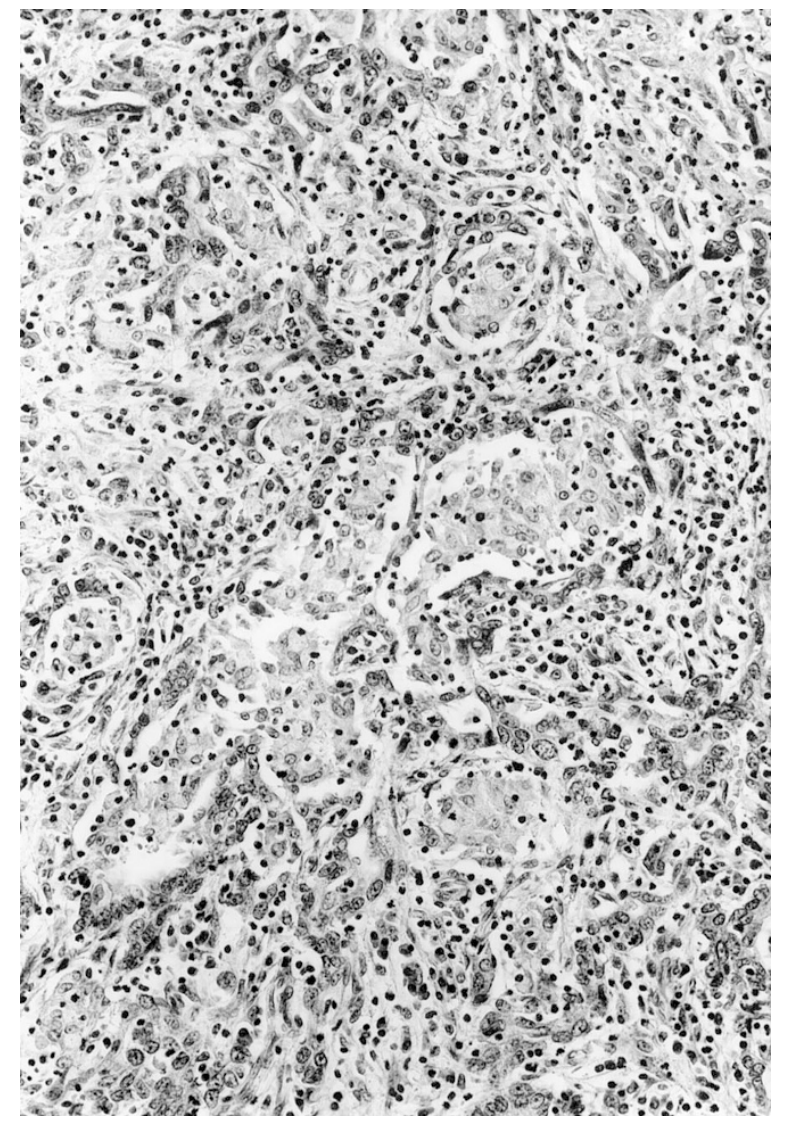

FIGURE 2. Granulomatous reaction was noted in Case 1.

tween Nucleotides 168,282 and 168,253 (corresponding to the B95-8 sequence). There were also five point mutations at positions $168320(A \rightarrow G)$, $168308(\mathrm{~T} \rightarrow \mathrm{C}), 168295(\mathrm{~A} \rightarrow \mathrm{T}), 168285(\mathrm{C} \rightarrow \mathrm{G})$, and $168225(\mathrm{~T} \rightarrow \mathrm{A})$.

\section{DISCUSSION}

LELC is a tumor with morphological features identical to undifferentiated nasopharyngeal carcinoma that occurs outside the nasopharynx (5). The tumor has been reported in a variety of organs, including stomach (6), salivary gland $(7,8)$, lung $(9)$, thymus $(10,11)$, skin (12), uterine cervix (13), trachea (14), ureter (15), urinary bladder (16), vagina (17), and vulva (18). To the best of our knowledge, only three cases of LELC have been reported in the liver. In the present report, we present two additional cases. The summary of the reported cases of hepatic LELC is listed in Table 2. The patients included three women and two men. Their ages ranged from 41 to 71 years. They presented with liver nodules, abdominal fullness, or epigastralgia. Three of the cases metastasized to lymph nodes in the portal region at the first operation or during the follow-up, and three of the five cases were demonstrated to have the presence of EBV. Of the five cases, one was a pure LELC, and the other four 


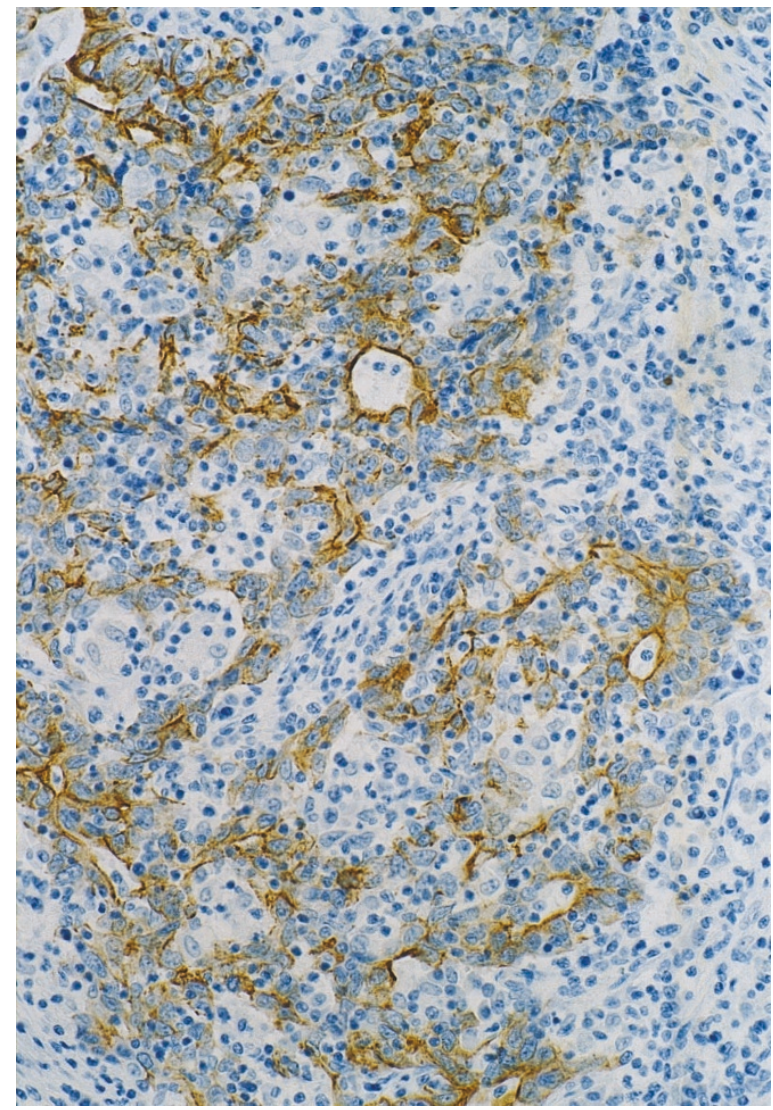

FIGURE 3. The tumor cells were immunoreactive with cytokeratin 19.

cases were mixed with ordinary adenocarcinoma. Both components merged together, indicating that the lymphoepithelioma-like component was transforming from the ordinary adenocarcinoma. In the present series, Case 1 also showed a marked granulomatous reaction. It was not uncommon in the LELC of other sites. But it had not been described in the LELC of the liver before.

Immunohistochemical study has been done on only 2 of the 3 previously reported hepatic LELCs $(2,3)$. The case reported by Vortmeyer et al. (2) was negative for CEA but positive for AE1/AE3 and EMA. The case reported by Kim et al. (3) was immunoreactive with CK 19 but negative for CEA and AE3. Although most cholangiocarcinomas are positive for CEA (19), our cases were not immunoreactive with CEA. They were immunoreactive with CK 7 and CK 19-9 but unstained by CK20. The immunophenotypes were compatible with cholangiocarcinoma (20). No tumor was also detected in any other sites. The stromal lymphoid cells were predominantly composed of CD3(+) T-cells. It was consistent with LELCs of other sites (5). The neoplastic cells were negative for CD21, which is the EBV receptor. The finding was identical to the previous report by Vortmeyer et al. (2).

EBV has been shown in LELC, especially in stomach (6), salivary glands $(7,8)$, lung (9), and thymus

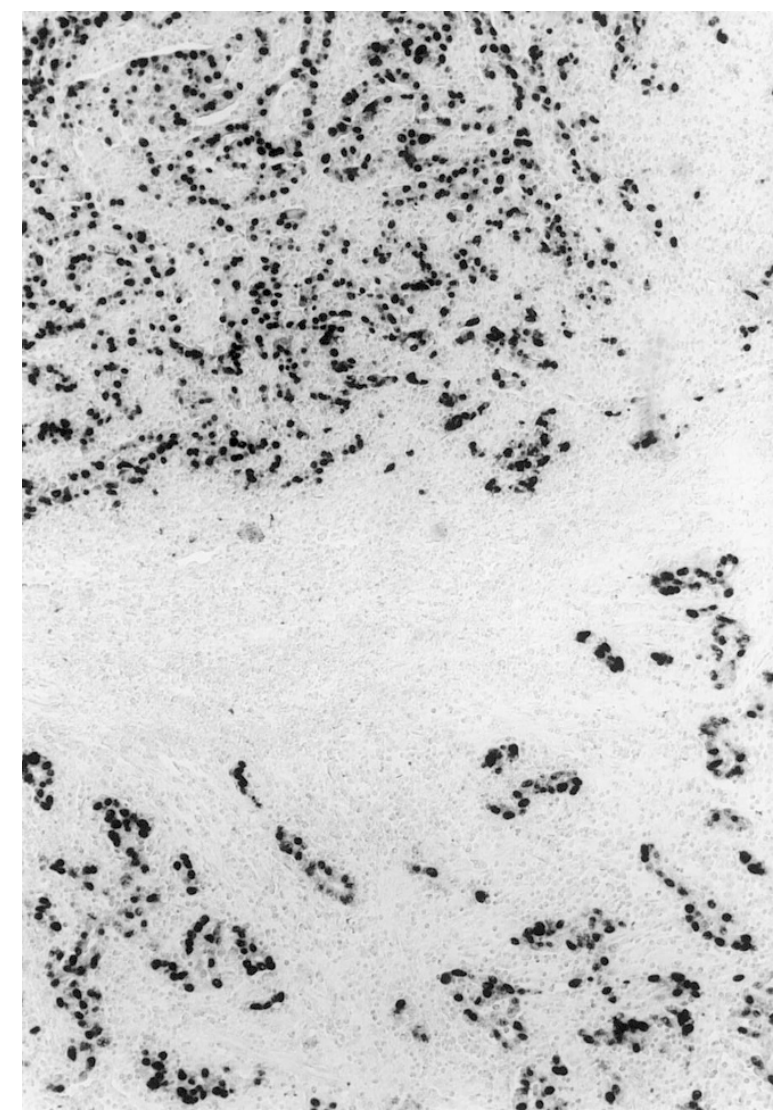

FIGURE 4. Positive nuclear EBER signal was seen in both ordinary adenocarcinoma and lymphoepithelioma-like carcinoma (Case 1). The stromal inflammatory cells were negative.

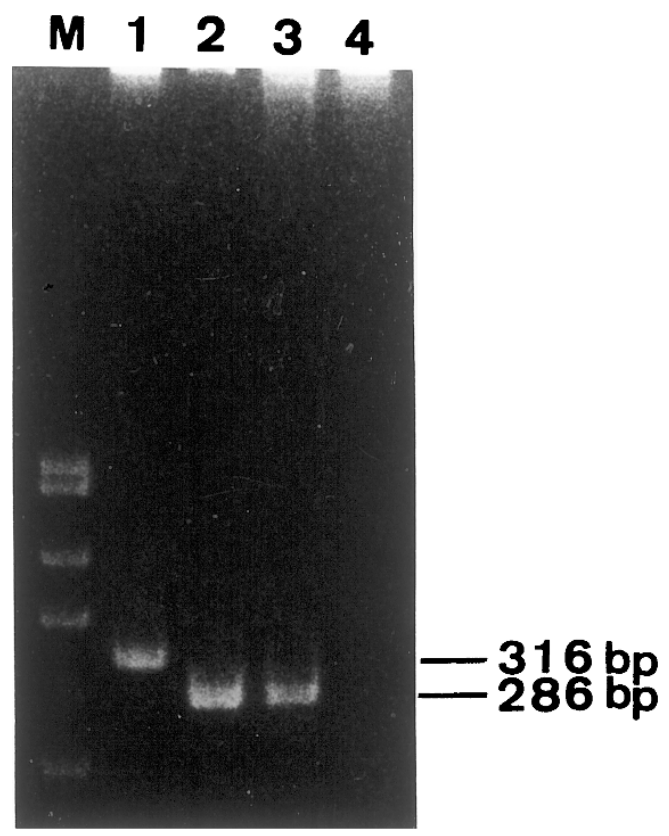

FIGURE 5. Analysis of polymerase chain reaction (PCR) products from Exon 3 of the LMP-1 gene. DNA fragments of $316 \mathrm{bp}$ and $286 \mathrm{bp}$ were generated with the B95-8 cells (Lane 1 ) and plasmid pT7 strain (Lane 2). Case 1 (Lane 3) had a 286-bp product, which was the same as that from plasmid pT7. But Case 2 (Lane 4) showed no PCR products. 
TABLE 2. Summary of the Reported Cases of Lymphoepothelioma-like Carcinoma of the Liver

\begin{tabular}{|c|c|c|c|c|c|c|c|}
\hline $\begin{array}{l}\text { Case } \\
\text { No. }\end{array}$ & Author(Ref. No.) & Age/Sex & Site/Size (cm) & Symptom & EBV & Outcome & Remarks \\
\hline 1 & Hsu et al. (1) & $47 / \mathrm{F}$ & $\mathrm{L} / 10$ & $\begin{array}{l}\text { Abdominal fullness } \\
\text { mass }\end{array}$ & + & $\begin{array}{l}\text { Lymph node, lung, rib, } \\
\text { and spleen metastasis }\end{array}$ & Malaria infection \\
\hline 2 & Vortmeyer et al. (2) & $71 / \mathrm{F}$ & Porta hepatis/5 & Liver nodule & + & Lymph node metastasis & \\
\hline 3 & Kim et al. (3) & $64 / \mathrm{M}$ & $\mathrm{R} / 2$ & Liver nodule & - & & \\
\hline 4 & Chen et al. (this article) & $67 / \mathrm{F}$ & $\mathrm{R} / 5$ & $\begin{array}{l}\text { Right upper quadrant } \\
\text { pain }\end{array}$ & + & Lymph node metastasis & \\
\hline 5 & Chen et al. (this article) & $41 / \mathrm{M}$ & $\mathrm{L} / 2.5$ & Epigastralgia & - & $\begin{array}{l}\text { Alive and well at } 8 \\
\text { months }\end{array}$ & \\
\hline
\end{tabular}

F, female; M, male; R, right; L, left; EBV, Epstein-Barr virus.

(10). Hepatic LELCs were also associated with EBV infection because two of the three previously reported intrahepatic cholangiocarcinoma with lymphoepithelioma-like component are associated with EBV in both ordinary adenocarcinoma and lymphoepithelioma-like components $(1,2)$. EBV was also identified in one of our cases. All EBVrelated hepatic LELC occurred in women. But pure cholangiocarcinomas were not related to EBV infection (21). EBV has been long implicated in the pathogenesis of LELCs (5). Southern blot analysis has demonstrated that LELC of the liver is a clonal proliferative disease $(1,2)$, indicating that the EBV infection occurred before the monoclonal proliferation of the LELC. LMP-1 is an integral membrane protein containing 386 amino acids and is encoded by the BNLF gene (also called LMP-1 gene) of EBV (22-24). LMP-1 is considered to be a viral oncogene because of its capacity to transform rodent fibroblasts in vitro and render them tumorigenic in nude mice (25). LMP-1 also serves as a target for T-cellmediated cytotoxicity (26). Any mutations in the LMP-1 gene that result in failure of recognition by $\mathrm{T}$ cells would allow the LMP-1 variant to escape immunologically mediated elimination (27). DNA sequencing of the LMP-1 gene in hepatic LELC reported by Vortmeyer et al. (2) showed no deletion of the LMP-1 gene as compared with the standard sequence of the EBV strain B95-8. In our series, Case 1 had a 30-bp deletion in Exon 3 of the LMP-1 gene, which was different from that reported by Vortmeyer et al. (2). In addition, five point mutations were present in Exon 3. The significance of the 30-bp deletion and five point mutations of the LMP-1 gene remains unclear. The deletion strain is prevalent in Taiwan, is not restricted to nasopharyngeal carcinoma, and was also found in throat washings of healthy individuals (28). Therefore, the clinicopathologic significance of the 30-bp deletion of Exon 3 of the LMP-1 gene in hepatic LELC warrants further investigation.

\section{REFERENCES}

1. Hsu HC, Chen CC, Huang GT, Lee PH. Clonal Epstein-Barr virus associated cholangiocarcinoma with lymphoepithelioma-like component. Hum Pathol 1996;27:848-50.
2. Vortmeyer AO, Kingma DW, Fenton RG, Curti BD, Jaffe ES, Duray PH. Hepatobiliary lymphoepithelioma-like carcinoma associated with Epstein-Barr virus. Am J Clin Pathol 1998; 109:90-5.

3. Kim YB, Park YN, Han JY, Hong KC, Hwang TS. Biliary lymphoepithelioma-like carcinoma not associated with Epstein-Barr virus. Arch Pathol Lab Med 1999;123:441-3.

4. Knecht H, Bachmann E, Brousset P, Sandvej K, Nadal D, Bachmann F, et al. Deletions within the LMP1 oncogene of Epstein-Barr virus are clustered in Hodgkin's disease and identical to those observed in nasopharyngeal carcinoma. Blood 1993;82:2937-42.

5. Iezzoni JC, Gaffey MJ, Weiss LM. The role of Epstein-Barr virus in lymphoepithelioma-like carcinoma. Am J Clin Pathol 1995;103:308-15.

6. Shibata D, Tokunaga M, Uemura Y, Sato E, Tanaka S, Weiss LM. Association of Epstein-Barr virus with undifferentiated gastric carcinomas with intense lymphoid infiltration. Am J Pathol 1996;139:469-74.

7. Saw D, Lau WH, Ho JHC, Chan JK, Ng CS. Malignant lymphoepithelial lesion of the salivary gland. Hum Pathol 1986; 17:914-21.

8. Kuo T, Hsueh C. Lymphoepithelioma-like salivary gland carcinoma in Taiwan: a clinicopathological study of nine cases demonstrating a strong association with Epstein-Barr virus. Histopathology 1997;31:75-82.

9. Pittaluga S, Wong MP, Chung LP, Loke SL. Clonal EpsteinBarr virus in lymphoepithelioma-like carcinoma of the lung. Am J Surg Pathol 1993;17:678-82.

10. Leyvraz S, Henle W, Chahinian AP. Association of EpsteinBarr virus with thymic carcinoma. N Engl J Med 1985;312: 1296-9.

11. Wu TC, Kuo T. Study of Epstein-Barr virus early RNA 1 (EBER1) expression by in situ hybridization in thymic epithelial tumors of Chinese patients in Taiwan. Hum Pathol 1993;24:235-8.

12. Ferlicot S, Plantier F, Rethers L, Bui AD, Wechsler J. Lymphoepithelioma-like carcinoma of the skin: a report of 3 Epstein-Barr virus (EBV)-negative additional cases. Immunohistochemical study of the stroma reaction. J Cutan Pathol 2000;27:306-11.

13. Mills SE, Austin MB, Randall ME. Lymphoepithelioma-like carcinoma of the uterine cervix. A distinctive, undifferentiated carcinoma with inflammatory stroma. Am J Surg Pathol 1985;9:883-9.

14. Onizuka M, Doi M, Mitsui K, Ogata T, Hori M. Undifferentiated carcinoma with prominent lymphocytic infiltration (so-called lymphoepithelioma) in the trachea. Chest 1990; 98:236-7.

15. Ng KF, Chen TC, Chang PL. Lymphoepithelioma-like carcinoma of the ureter. J Urol 1999;161:1277-8.

16. Dinney CPN, Ro JY, Babaian J, Johnson DE. Lymphoepithelioma of the urinary bladder: a clinicopathologic study of 3 cases. J Urol 1991;149:840-2. 
17. Dietl J, Horny HP, Kaiserling E. lymphoepithelioma-like carcinoma of the vagina: a case report with special reference to the immunophenotype of the tumor cells and tumorinfiltrating lymphoreticular cells. Int J Gynecol Pathol 1994; 13:186-9.

18. Axelsen SM, Stamp IM. Lymphoepithelioma-like carcinoma of the vulvar region. Histopathology 1995;27:281-3.

19. Balaton AJ, Nehama-Sibony M, Gotheil C, Callard P, Baviera EE. Distinction between hepatocellular carcinoma, cholangiocarcinoma, and metastatic carcinoma based on immunohistochemical staining for carcinoembryonic antigen and for cytokeratin 19 on paraffin sections. J Pathol 1988;156:305-10.

20. Rullier A, Bail BL, Fawaz R, Blanc JF, Saric J, Bioulac-Sage P. Cytokeratin 7 and 20 expression in cholangiocarcinomas varies along the biliary tract but still differs from that in colorectal carcinoma metastasis. Am J Surg Pathol 2000;24: 870-6.

21. Ozaki S, Harada K, Watanabe K, Furubo S, Tsui WM, Nakanuma Y. Absence of Epstein-Barr virus (EBV) in intrahepatic cholangiocarcinoma confirmed by lack of EBV-coded nuclear RNA and latent membrane protein-1. Histopathology 2000;36:50-3.

22. Bankier AT, Deininger PL, Satchwell SC, Baer R, Farrell PJ, Barrell BG. DNA sequence analysis of the EcoRI Dhet fragment of B95-8 Epstein-Barr virus containing the terminal repeat seauences. Mol Biol Med 1983;1:425-45.
23. Fennewald S, van Santen V, Kieff E. Nucleotide sequence of a mRNA transcribed in latent growth-transforming virus infection indicates that it may encode a membrane protein. J Virol 1984;51:411-9.

24. Hudson GS, Farrell PJ, Barrell BG. Two related but differentially expressed potential membrane protein encoded by the EcoRI Dhet region of Epstein-Barr virus B95-8. J Virol 1985; 53:528-35.

25. Wang D, Liebowitz D, Kieff E. An EBV membrane protein expressed in immortalized lymphocytes transforms established rodent cells. Cell 1985;43:831-40.

26. Murray RJ, Kurilla MG, Brooks MJ, Thomas WA, Rowe M, Kieff $\mathrm{E}$, et al. Identification of target antigen for the human cytotoxic T cell response to Epstein-Barr virus (EBV). Implication for the immune control of EBV-positive malignancies. J Exp Med 1992;176:157-68.

27. Trivedi $\mathrm{P}, \mathrm{Hu}$ LF, Chen F, Christensson B, Masucci MG, Klein $\mathrm{G}$, et al. Epstein-Barr virus (EBV)-encoded membrane protein LMP 1 from a nasopharyngeal carcinoma is nonimmunogenic in a murine model system, in contrast to a B-cell derived homologue. Eur J Cancer 1994;30A:84-8.

28. Chang TS, Su IJ, Chung PJ, Shu CH, Ng CK, Wu SJ, et al. Detection of an Epstein-Barr virus variant in $\mathrm{T}$ cell lymphoma tissues identical to the distinct strain observed in nasopharyngeal carcinoma in the Taiwanese population. Int J Cancer 1995;62:673-7. 